\title{
Limits of Technological Efficiency of Shale Oil Production in the USA
}

\author{
Alexander Malanichev \\ Visiting Professor, a_malanichev@list.ru \\ New Economic School, Skolkovskoe str. 45, Moscow, 121353, Russian Federation
}

\begin{abstract}
The development of the shale oil extracting technology revolution in the United States led to the rapid growth of its production and reduced the related costs to an acceptable level. The shale oil revolution dramatically influenced the global oil market and was a key factor in the reduction of oil prices in 2014-2016. This paper investigates the problems of long-term forecasting of shale oil production and the productivity of drilling rigs. This research applies an asymmetric bell-shaped function using the OLS approach. This function is derived as an analytical solution of the differential equation of oil production. Another contribution of this study is the asymmetric function, which correlates better with the data on the extraction of traditional and non-traditional oil resources.
\end{abstract}

Abstract
Keywords: shale oil production; technological efficiency; institutional factors; bell-shaped curve fitting; rig productivity.
An analysis of the empirical data with the derived asymmetrical bell-shaped curve shows that the productivity of drilling rigs would peak by 2026 at 1,200 bbl per day, which is two times higher than the current level. The peak of production would correspond to the maximum oil production of $11.3 \mathrm{mln}$ bbl per day and to technically recoverable resources of $96 \mathrm{bln}$ bbl. This could mean that starting from 2023, the volume of oil shale oil production in the US may not be enough to meet growing global demand for oil and other resources with even higher production costs. The theoretically grounded and practically tested asymmetrical bell-shaped curve can serve as one of the tools for assessing the long-term impact of technological innovation over the course of Foresight studies for the oil and gas complex.

Citation: Malanichev A. (2018) Limits of Technological Efficiency of Shale Oil Production in the USA. Foresight and STI Governance, vol. 12, no 4, pp. 78-89.

DOI: 10.17323/2500-2597.2018.4.78.89 
I ncreased shale oil production in the United States was one of the major factors behind the dramatic decline in oil prices in 2014-2016. Shale oil is light with a low sulphur content contained in tight reservoirs [Mănescu, Nuño, 2015]. The short investment cycle allowed the US shale oil industry to push OPEC out of its position as the price regulator on the global oil market [Baffes, 2015].

Oil production is affected by several groups of factors (geological, technological, economic, and political), including specific features of the industry's regulation. In the long term, geological and technological factors become decisive [Benes et al., 2012]: the more rapidly exploration and production technologies improve, the more hydrocarbons can be extracted and marketed under comparable economic conditions, and the higher the revenues will be.

Several engineering- and geology-based approaches were applied to model the geological and technological factors affecting oil production [Brandt, 2010]. We mean a set of hypotheses concerning production profiles throughout the oil field's life, usually presented in the form of bell-shaped curves. The most popular is the symmetric bell-shaped Hubbert curve which allowed researchers to predict the peak of oil production in the United States between 1965 and 1970 [Hubbert, 1956].

The main advantage of the geological engineering approach is its taking into account the non-linear nature of production growth over time, plus there is no need to predict oil price behavior in the long term. The flaws of this approach include its insufficient consideration of major oil production limitations (such as the need to maintain material balance and natural production decline). Production profiles are set a priori, while the quality of empirical data approximations is verified using mathematical procedures [Semenychev et al., 2014].

To deal with these shortcomings, [Malanichev, 2017a] proposed an ordinary differential equation that describes oil production growth taking into account the need to maintain material balance in oil reservoirs and the natural production decline. The Hubbert symmetric bell-shaped curve is a particular solution of this equation. However, since long-term oil production dynamics mostly remain asymmetrical (Sorrel et al., 2009), the proposed method required certain adjustments.

The first objective of this paper is to find an analytical solution for the oil production differential equation precisely in the form of an asymmetric bell-shaped curve. This will allow one to take into account physical conditions, clearly interpret the curve's coefficients, and ensure better compliance with observational data. The practical result of empirical data analysis based on the above curve will be a long-term production forecast and an estimate of technically recoverable reserves in US shale oil fields.

The second objective is to review key technologies, and other prerequisites that made the "shale revolution" possible in the United States by identifying a key technological efficiency indicator for oil production and preparing a long-term forecast of its growth. It is assumed that the technological curve is less variable than production volume, as it is less dependent upon the price factor.

This study was based on shale oil production data at seven key US fields for 2007-2017 (Fig. 1), presented in the Drilling Productivity Report of the US Energy Information Administration (EIA) [EIA, 2018]. Total oil production is measured using a set of indicators for individual formations, while drilling rig' productivity is calculated as a weighted average.

\section{Figure 1. Location of US shale oil fields under consideration}

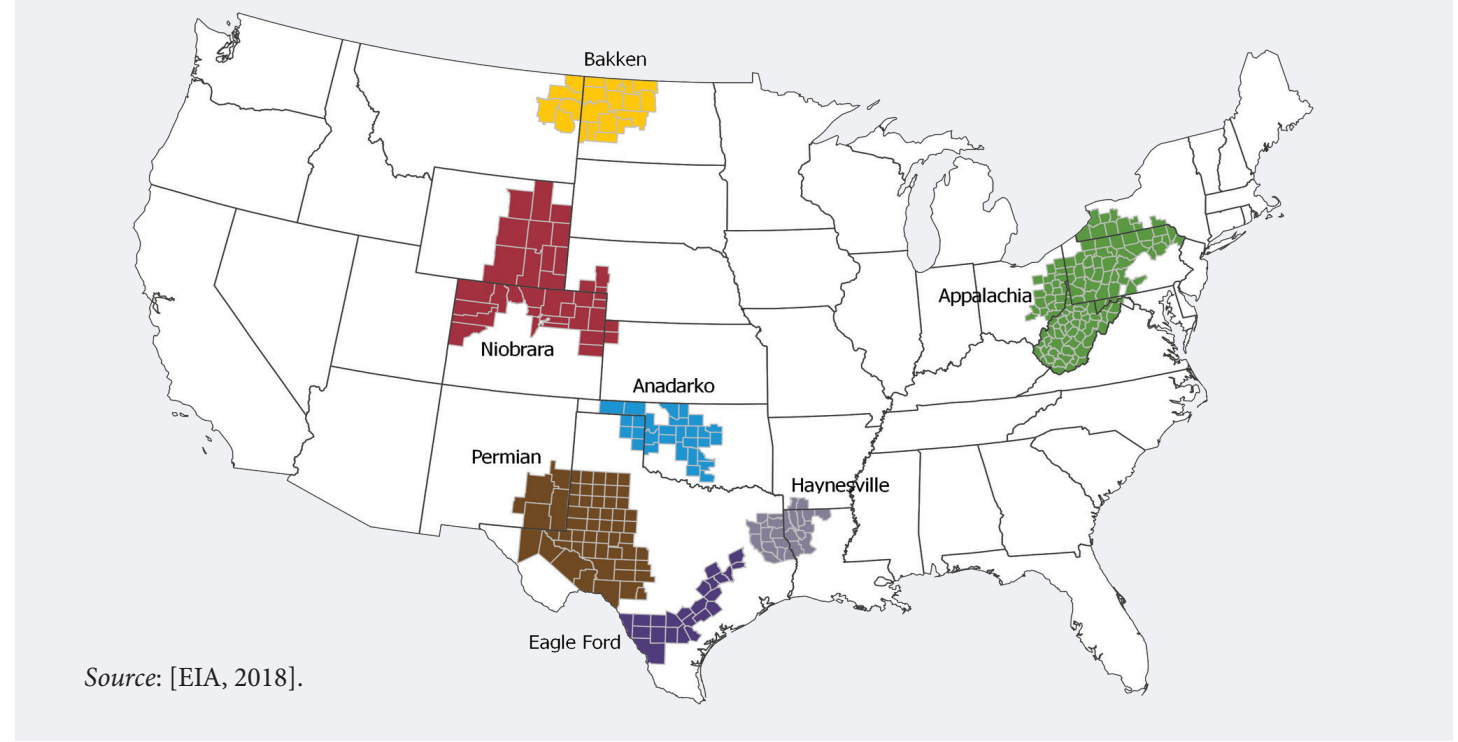




\section{Technological and Institutional Factors of the "Shale Revolution"}

The rapid growth of hydrocarbon production from tight reservoirs in the United States is due to a number of favorable technological and institutional factors. The first group includes the development of horizontal drilling and multiple fracturing technologies, new tools and capabilities for the development of complex wells, an extended range of chemical and physical methods of affecting the reservoir to increase the flow of hydrocarbons to the bottom of the well, and so on. Institutional factors include ownership guarantees, a transparent mechanism for getting access to oil-bearing areas, a developed service market, small and medium oil and gas businesses, good transport infrastructure, and a large financial market [Shafrannik, Kryukov, 2016].

The increased share of hydrocarbons produced from non-conventional fields by the US oil and gas sector was achieved after a long period of developing and improving relevant production technologies (Table 1). Due to the lack of breakthrough inventions, the existing approaches to combining horizontal drilling, hydraulic fracturing, and 3D seismic surveying have been improved over the past 10-15 years [Ivanov, 2017a]:

- Repeated hydraulic fracturing. According to Halliburton, this technology increases recoverable reserves by $80 \%$ and cuts costs by $66 \%$. In 2015 , the number of fracturing stages reached 50 and their density was reduced to 3 meters. Proppant concentration increased to $3 \mathrm{t} / \mathrm{m}$. Length of horizontal trunk exceeded 3 kilometers. Production via carbon dioxide injection after fracturing is now being promoted.

- Cluster drilling, which is applied at $58 \%$ of wells, amounts to drilling vertical wells in a section of the grid and then connecting them with horizontal wells. This reduces well costs by $15-30 \%$ and significantly reduces drilling time.

- Analytical methods for processing 3D seismic data, "big data", and computer modeling are being developed by oil and gas companies and by technology services providers. For example, the FracFit Baker Hughes technology allows one to collect and analyze data to quickly and efficiently complete and stimulate shale wells, resulting in a $45 \%$ increase in production.

Along with improved production technologies, a key prerequisite of the "shale revolution" in the US was the development of financial technologies. While oil prices remained high (in 2005-2014), the tight oil sector has managed to attract significant financial resources from leading world markets, among other things because money was readily available due to the Federal Reserve's low interest policy [Zhukov, Zolina, 2017]. When the market situation deteriorated in 2015-2017, the hedging of price-related risks prevented US crude oil production from dropping below the June 2014 level (when prices exceeded $\$ 100$ per barrel). Guaranteed sales at a relatively high price in a falling market helped to maintain the financial stability of oil-producing companies in the US and provided them with a steady flow of liquidity.

In contrast, on a growing market hedging turns out to be a constraining factor. According to Bloomberg, in 2018 63\% of expected revenues were hedged at the average price of $\$ 48.2$ per barrel, while the actual price of a barrel of WTI oil at the beginning of the year was $\$ 64$ [Denning, 2017]. Thus, hedging on the oil market turns out to be ineffective with an upward price trend, but ensures companies' stability with a downward one.

Hedging was a financial driver of the US "shale revolution" and remains an essential element of the developed institutional business environment in the United States. Other components of this environment include the following tools and characteristics [Shafrannik, Kryukov, 2016]:

- The established institution of private land and subsoil ownership. In the US, the landowner owns the subsoil and has the right to geological exploration, development, and mining by default, while the advanced rules and mechanisms make obtaining relevant authorizations simple and straightforward.

- The largest fleet of drilling rigs (in 2011 the number of simultaneously operating rigs exceeded 1,800); most of them allow one to drill long horizontal wells. This is more than the combined fleet of the former Soviet republics, Saudi Arabia, and Canada. It should be noted that after the rig fleet stabilized at 800 , the growth of drilling volumes was mainly due to increased productivity, as the equipment was upgraded.

- Investment and tax incentives to keep marginal wells operational. The resulting huge number of drilled wells, combined with the newly acquired and systematized knowledge, facilitated the US oil and gas sector's taking a new development path.

- Developed transport infrastructure, including road and special-purpose networks (such as pipelines and terminals), with free and non-discriminatory access.

- Numerous independent small and medium oil companies that are more flexible and willing to take on the risk of working with small fields and hard-to-reach resources. Such players' share is almost $60 \%$ 
of hydrocarbon production in the United States, which was the reason why the oil recovery rate in the US over the past 20-30 years grew from $25-28 \%$ to $40 \%$.

- Less strict environmental requirements for hydraulic fracturing. Influenced by the US Vice President (formerly Executive Director and Chairman of the Board of Directors of Halliburton) Dick Cheney, in 2005 the US Congress took fracturing technology out of the Environmental Protection Agency's (EPA) supervision and removed it from the coverage of the federal water laws [Glushenkova, 2015]. Shale oil production in the country is mainly concentrated in sparsely populated areas of nonagricultural states such as Oklahoma, Texas, Nevada, etc. However, even there the development of shale deposits may pose a threat to the environment. Firstly, if technologies are applied carelessly, drinking water extracted from underground reservoirs can be polluted. Secondly, oil production exacerbates seismic instability, even in relatively safe areas. Thirdly, it may be accompanied by emissions of methane and other greenhouse gases. Fourthly, there is a risk of contamination and subsidence of soil in production areas and the associated problem of cleaning and disposing of drilling mud and water used for hydraulic fracturing.

The favorable institutional environment for the development of production technologies in the US contributed to the development of unconventional hydrocarbon deposits, while the "learning curve" has led to increased oil recovery from the drilled wells (Fig. 2).

At the key Permian formation reviewed above, the average well oil recovery was steadily growing over the observation period (from 2007) and by 2017, the new flow rates have exceeded $450 \mathrm{bbl} . / \mathrm{d}$. The average well output is a representative indicator for describing the quality of hydrocarbon reserves and productivity, but not the drilling efficiency. The oil production per drilling rig is a more comprehensive indicator. This data is readily available due to the monthly monitoring of the seven key formations published in the Drilling Performance Report [EIA, 2018].

\section{Growth of Drilling Rig Productivity}

The productivity of drilling rigs is directly reflected in the level of oil production in the US shale deposits and technically recoverable reserves. The higher the productivity, the higher the output given the same number of active rigs.

Since 2007, the productivity of the average drilling rig grew by 15 times reaching $625 \mathrm{bbl} / / \mathrm{d}$ by the end of 2017 and it continues to increase (Fig. 3). In the context of high oil prices in 2010-2014, this indicator grew due to the technological factor, i.e., the classic proliferation of innovations [EIA, 2016]. Since the end of 2014, productivity growth was also influenced by low oil prices.

As a result of the falling oil prices in 2014-2016, the number of active drilling rigs dropped from 1,549 in October 2014 to 317 in May 2016. Such a rapid decrease resulted in an equally fast increase in productivity, which by August 2016 peaked at $711 \mathrm{bbl} . / \mathrm{d}$, mainly due to cyclical rather than technological factors [Rystad Energy, 2016]. While the volume of drilling and the fleet of rigs were being reduced, only the

Table 1. The main stages of developing key tight oil production technologies in the US

\begin{tabular}{|c|l|}
\hline Year & \multicolumn{1}{|c|}{ Technology, application } \\
\hline 1929 & Drilling of the first horizontal well in Texas \\
\hline 1947 & First hydraulic fracturing in Kansas \\
\hline 1949 & First cost-effective hydraulic fracturing in Oklahoma \\
\hline 1979 & $\begin{array}{l}\text { Development of the Barnett Formation begins: the first } \\
\text { shale formation fracture }\end{array}$ \\
\hline 1986 & $\begin{array}{l}\text { The first multistage hydraulic fracturing of a shale } \\
\text { formation (seven stages) }\end{array}$ \\
\hline 1992 & The first 3D seismic survey in Texas \\
\hline 1997 & $\begin{array}{l}\text { The first application of a water-based reagent for fracturing } \\
\text { the Barnett formation }\end{array}$ \\
\hline 2000 & $\begin{array}{l}\text { Drilling of the first horizontal well in the Barnett } \\
\text { formation }\end{array}$ \\
\hline 2002 & $\begin{array}{l}\text { Horizontal drilling combined with hydraulic fracturing in } \\
\text { the Barnett formation }\end{array}$ \\
\hline Source: [Zolina, 2014]. \\
\hline
\end{tabular}

Figure 2. Oil production from the average well in the Permian formation in 2014-2017

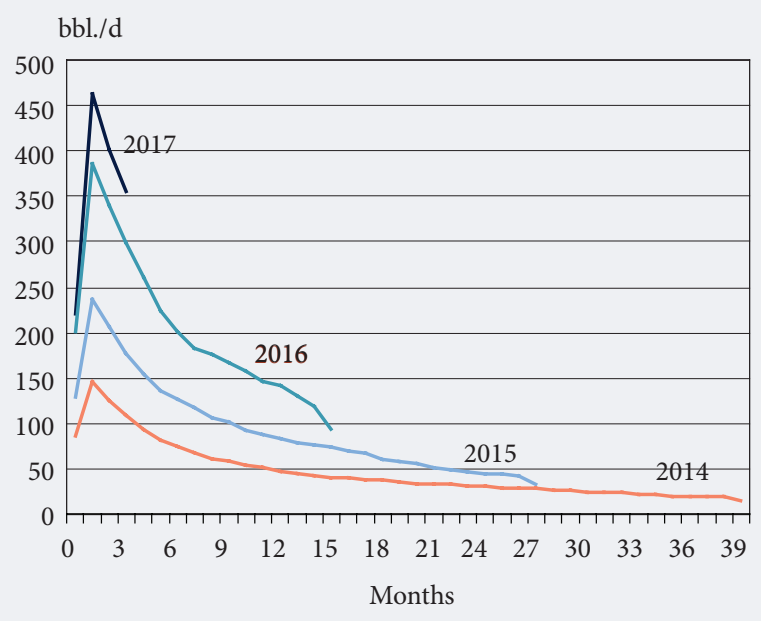

Source: composed by the author based on [EIA, 2017]. 
Figure 3. Weighted average productivity of drilling rigs in seven fields, and the number of drilling rigs

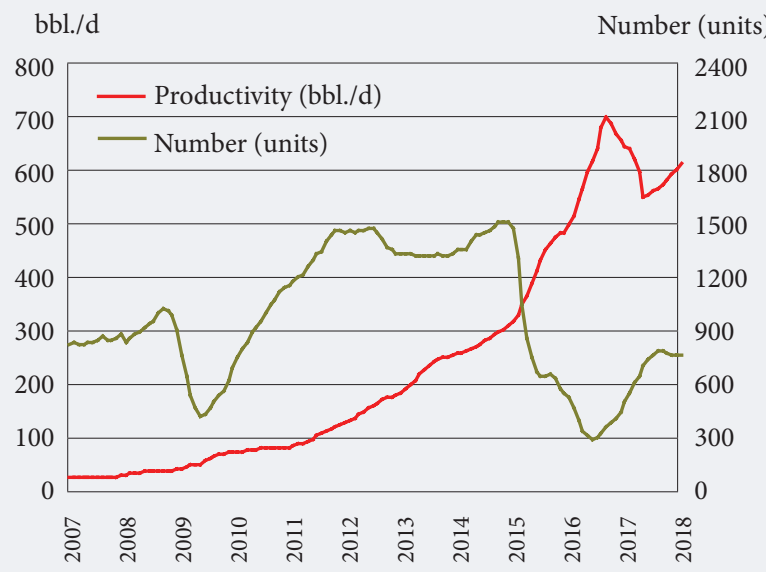

Source: composed by the author based on [EIA, 2018].
Figure 4. Drilling rigs' productivity

in the largest US fields, and the weighted average for seven fields

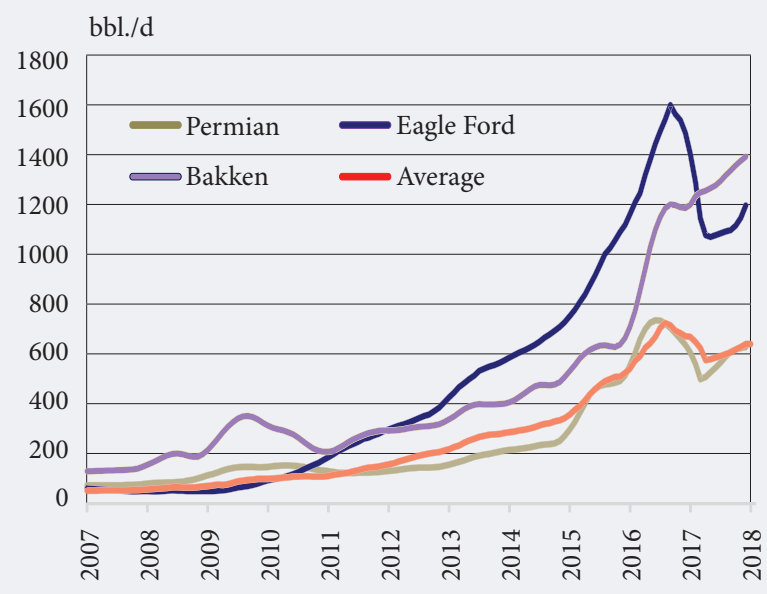

Source: composed by the author based on [EIA, 2018].

most promising areas were developed and only the most efficient (high grade) rigs remained in operation [Hoza, 2015]

The upward price trend of 2016 led to an increase in drilling activity beginning in June. However, the growing fleet of operating drilling rigs, increased drilling volumes, and the development of less rich areas resulted in a cyclical decrease in productivity, from 711 bbl./d in August 2016 to 586 bbl./d in August 2017. The stagnation of drilling, in its turn, "suspended" the cyclic factor, so productivity began to grow again due to the long-term technological trend associated with increased production efficiency. Accordingly, by the end of 2017 it reached $625 \mathrm{bbl} . / \mathrm{d}$.

Thus, in the short term, drilling rigs' productivity is significantly affected by production volume and the level of drilling (the cyclical factor), while the geological (gradual depletion of deposits) and technological factors act as long-term ones [Hughes, 2016]. Along with them, the average drilling productivity for all fields (Fig. 4) is also affected by the fourth factor, namely the spatial one. It amounts to the fact that drilling rig productivity and output vary between different fields, depending, among other things, on the rate of their reserves' change.

At the end of 2017, the largest Permian oil field in the US produced 2.8 million barrels per day, or $43 \%$ of total shale oil production in the country (Fig. 5). Furthermore, the production at this field is growing at

\section{Figure 5. Structure of production at US fields (as of December 2017) (\%)}

$$
\text { (Total }=\stackrel{\text { a) }}{6.4} \text { milliout }
$$

Total $=6.4$ million bbl..$/ \mathrm{d})$

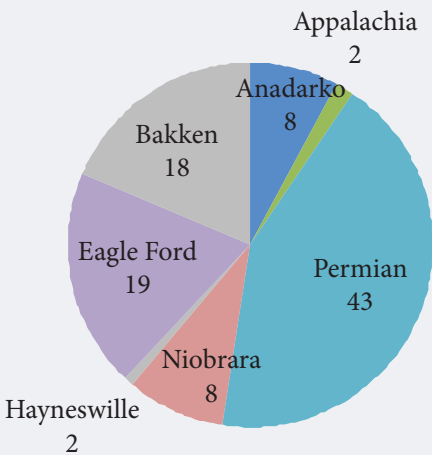

b) contribution to growth (total $=\mathbf{0 . 0 9}$ million bbl./d)

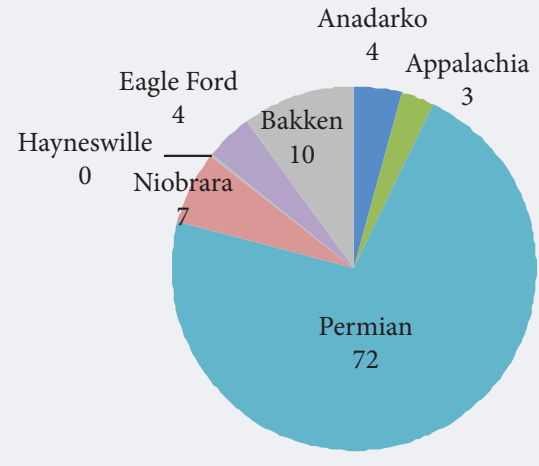

Source: composed by the author based on [EIA, 2018]. 
the most rapid rate, while Permian's contribution to the growth of shale oil production reached $72 \%$. This is followed by the Eagle Ford and Bakken fields ( $20 \%$ and $18 \%$, respectively), with a much more modest contribution to production growth (at $4 \%$ and $10 \%$, respectively). This is due to the reduced number of operating drilling rigs, so production only grows due to increased per rig output.

The geological features of the fields and the degree of their depletion are quite different, leading to significant variations in drilling rig productivity levels. For example, at the most valuable Permian field at the end of 2017, productivity was close to the average value ( $614 \mathrm{bbl} . / \mathrm{d}$ ), while the maximum of 1,383 bbl./d was recorded at Bakken and almost 1,185 bbl./d at Eagle Ford. However, the contribution of such high indicators is offset by the low drilling activity at the last two fields (Fig. 5b), so the average productivity for all fields is close to that of the Permian field (see Fig. 4).

The fifth factor affecting drilling rigs' efficiency is the share of wells drilled at the completion stage: the installation of casing, cementing, perforating, hydraulic fracturing, and so on, i.e., the operations that allow one to begin production. Part of the drilled wells go straight into the so-called backlog of drilled but uncompleted (DUC) wells. Well completion is often delayed due to the lack of available equipment and consumables, insufficient economic efficiency of production, or for speculative reasons [Rystad Energy, 2016]. The latter include rising oil prices or accelerated commissioning of wells if there is a downward price trend.

The number of DUC wells by the end of 2017 exceeded 7,000 [EIA, 2018], raising legitimate concerns about a significant increase in production when these wells are commissioned (completed) during an upward trend in oil prices [Ivanov, 2017b]. However, such expectations are subject to high uncertainty. For example, at the moment it is impossible to estimate the share of "dry" DUC wells, i.e., those unsuitable for commercial production, or their production costs, the rate of fleet deployment for hydraulic fracturing, the prospects for overcoming the shortage of proppant, and various other logistical constraints [IHS, 2015].

The dynamics of reserve wells' numbers display a growing trend when drilling and output grow amid rising oil prices. The reverse was observed only from February to November 2016, when, due to the insufficient volume of drilling, the queues to rent hydraulic fracturing equipment got shorter: in 10 months' time the number of reserve wells decreased by 925 , i.e., on average at the rate of 9.25 wells per month. Given the average per well output of $400 \mathrm{bbl} . / \mathrm{d}$, the added capacity provided an increase of 0.0037 million barrels per day, or just $1.5 \%$ of the new flow rates for the period under consideration.

As we see, out of the five drilling rig efficiency factors, only the technological (the development of production technologies) and geological ones (the depletion of hydrocarbon fields) are worthy of attention in the long term. The spatial factor and production from reserve wells along with output variations seem to have a significantly smaller impact. In the next section, a hypothesis is presented regarding the shape of the curve describing drilling rig productivity following the application of technological innovations and geological changes.

\section{Growth of Drilling Rig Productivity throughout the Field's Life Cycle}

The classic approach to studying the proliferation of innovations is based upon the technology life cycle concept [Mansfield, 1968]. In the course of numerous studies, it was found that the process of innovative products' penetration (diffusion) is best described by a logistic function whose graph can be presented as an S-shaped non-linear curve that reaches a certain saturation level [Little, 1981; Rogers, 2002]. Productivity growth at the early stages of technology implementation is slow, since the lack of experience requires a considerable amount of time to master it. The accumulation of experience by researchers, engineers, managers, and businessmen triggers a positive feedback loop that accelerates the diffusion of innovations and productivity growth.

Technology developers make significant efforts to maximize their returns but after a while the diminishing marginal utility law triggers negative feedback. When the technological limits of growth are reached, the cost of each unit of change increases exponentially and the S-shaped curve smooths over. Such dynamics are typical for most industries including the production of automobiles, ships, internal and external combustion engines, semiconductors, vacuum tubes, disk drives, etc. [Foster, 1986].

However, there are many limitations to using S-curves as prognostic tools [Schilling, Esmundo, 2009]. Firstly, the actual limits of a technology's efficiency are rarely known in advance and experts from different companies may have different opinions about this issue. Secondly, unexpected changes on the market, complementary (replacement) technologies, or individual components can both speed up and slow down a technology's life cycle. Thirdly, S-curves do not describe the proliferation of innovations in all industries equally well. For example, for fossil fuels (coal, gas, oil), energy generation technologies have the form of not S-shaped, but rather bell-shaped curves (Fig. 6). 
The bell-shaped curve describing the productivity of technologies for the extraction and use of fossil fuels can be explained as follows. After reaching its peak, productivity begins to decline due to two factors. The first is a significant slowdown or stabilization of the innovation's effect. The second is the exhaustion of the learning curve combined with the depletion of deposits and exhaustion of attractive sites ("sweet spots"), which forces companies to drill deeper and deeper and develop increasingly less rich deposits with lower extraction rates [Montgomery, O’Sullivan, 2017].

Industry experts also point out that a decline in drilling productivity is inevitable.

How long productivity will be growing is, of course, highly uncertain. However, the cyclical component will sooner or later lead to a growing trend changing to a downward one. The growth of productivity based on choosing the "sweetest spots" for development will soon come to an end [IHS, 2016].

In addition to the depletion of promising areas, a pressing problem with shale deposits is the reduced distance between wells.

A site can be drilled only once. In addition, productivity growth is limited by the distance between adjacent wells. An excessively dense grid of wells leads to reduced productivity. Empirical evidence suggests that adjacent wells may adversely affect one another. Though oil can be extracted more efficiently when wells are located close to each other, the per well recovery rate will drop and the overall output in the area will not increase [Hughes, 2016].

Thus, a hypothesis was suggested, and illustrated, that drilling rigs' productivity within the life cycle of a field can be described by a bell-shaped curve. Next, a mathematical formula will be derived for an asymmetric bell-shaped curve suitable for describing shale oil production and the growth of drilling rig productivity.

\section{The Asymmetrical Bell-Shaped Function}

The mathematical description of oil production technologies' efficiency can be found in literature that analyzes and forecasts hydrocarbon supply. Table 2 presents a classification of the various approaches to modeling this supply and references to sources with typical examples. A more complete review of the most common approaches can be found in [Brandt, 2010].

For the purposes of this paper we are primarily interested in the fourth approach, namely predicting production by fitting a bell-shaped curve. In our previous study [Malanichev, 2017a] we considered a set of assumptions for describing a theoretical oil production and drilling rigs productivity model using a symmetric bell-shaped curve proposed in 1838 for modeling population size [Verhulst, 1838] and then for predicting oil production volume in the United States [Hubbert, 1956].

\section{Table 2. Main approaches to forecasting oil production growth}

\begin{tabular}{|c|c|c|c|}
\hline No. & Approach & Description & Sources \\
\hline 1 & $\begin{array}{l}\text { Fitting natural production decline } \\
\text { curve }\end{array}$ & $\begin{array}{l}\text { Short-term production forecast for individual wells. } \\
\text { Geological and technological factors are taken into account. }\end{array}$ & $\begin{array}{l}{[\text { Arps, 1944; Clark, 2011; }} \\
\text { Malanichev, 2017c] }\end{array}$ \\
\hline 2 & $\begin{array}{l}\text { Superposition of natural } \\
\text { production decline curves }\end{array}$ & $\begin{array}{l}\text { Geological, technological, and economic factors are taken } \\
\text { into account. }\end{array}$ & $\begin{array}{l}\text { [Sorrel et al., 2009; } \\
\text { Malanichev, 2017b] }\end{array}$ \\
\hline 3 & "Bottom up" & $\begin{array}{l}\text { Based on plans for the development of new sites or fields } \\
\text { and their empirical production profiles. }\end{array}$ & [Sorrel et al., 2009] \\
\hline 4 & Fitting bell-shaped curve & $\begin{array}{l}\text { Long-term production forecast for the field. Geological and } \\
\text { technical factors are taken into account. }\end{array}$ & $\begin{array}{l}\text { [Hubbert, 1956; Semenychev } \\
\text { et. al., 2014; Malanichev, } \\
\text { 2017a; Kozlov, 2018] }\end{array}$ \\
\hline 5 & $\begin{array}{l}\text { Solving a differential equation } \\
\text { with a lagging argument }\end{array}$ & $\begin{array}{l}\text { Analysis of conditions leading to economic fluctuations. } \\
\text { Forecast based on analytical solution of a differential } \\
\text { equation. Geological and economic factors are taken into } \\
\text { account. }\end{array}$ & [Malanichev, 2018] \\
\hline 6 & Econometric & Forecast based on economic factors. & $\begin{array}{l}\text { [Kaufmann, Cleveland, 2001; } \\
\text { Afanasiev, 2016; Ermolina, } \\
\text { 2017] }\end{array}$ \\
\hline 7 & Optimal planning & $\begin{array}{l}\text { Solving the problem of optimal production planning, taking } \\
\text { into account the time value of money. }\end{array}$ & $\begin{array}{l}{[\text { Hotelling, 1931; Okullo et al., }} \\
\text { 2014] }\end{array}$ \\
\hline 8 & Combined & $\begin{array}{l}\text { Combines fitting of bell-shaped curve with economic factors } \\
\text { such as oil prices. }\end{array}$ & $\begin{array}{l}\text { [Benes et al., 2012; Zolina, } \\
\text { 2014; Ermolina, 2017] }\end{array}$ \\
\hline 9 & System imitation & $\begin{array}{l}\text { Takes into account numerous interconnected factors and } \\
\text { models the process of oil producers' making investment } \\
\text { decisions. }\end{array}$ & $\begin{array}{l}\text { [Davidsen, 1990; Makarov } \\
\text { et al., 2011] }\end{array}$ \\
\hline
\end{tabular}


Figure 6. Technological curves for the extraction and use of fossil fuels: technology performance ( $\mathrm{kWh}$ per \$1) vs $\mathrm{R} \& \mathrm{D}$ costs, $1990-2005$

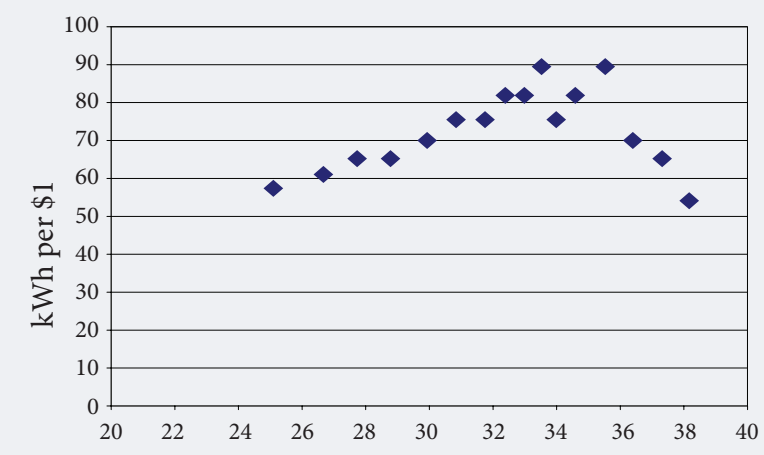

Total R\&D expenditures (\$ million, in constant 2005 prices)

Source: [Schilling, Esmundo, 2009].
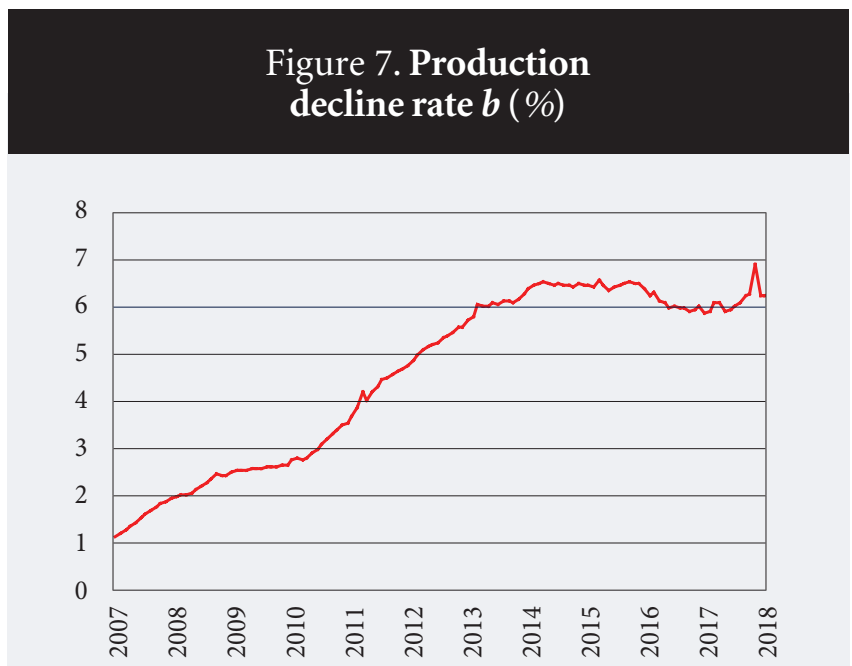

Source: composed by the author based on [EIA, 2018].

However, empirical evidence indicates that the production curve is asymmetrical. Rapidly increasing at the beginning of the development of a field, it reaches a peak and then slowly decreases. This asymmetrical bell-shaped profile with a flatter right side is typical of both conventional [Bierman, Biryukov, 2017] and unconventional [Coyne, 2017] hydrocarbon deposits.

In order to obtain an asymmetric bell-shaped curve, we will find an analytical solution of the differential production equation, making a number of simplifying assumptions [Malanichev, 2017a]. In the shale oil production case, the changes include the development of new wells drilled in the current month and reduced production from existing wells (drilled before the month in question). This balance can be described using an ordinary differential equation of the first order:

$\frac{d q}{d t}=e \cdot N-b \cdot q$

where:

$Q$ is oil production volume (million bbl./d);

$e \cdot N$ is oil production from new wells (million bbl./d). The well is considered new for one month after it was completed and commissioned;

$e$ is drilling rig productivity (bbl./d). Calculated as the number of barrels of oil extracted during the month from the wells drilled by one rig during the same period;

$\mathrm{N}$ is the number of active rigs that drilled new wells during the same month;

$b \cdot q$ is the rate of natural production decline in line with the exponential decline law. [Malanichev, 2017c] also considers other laws that affect the dynamics of production decline (the harmonic and hyperbolic ones);

$b$ is the empirical production decline rate.

A distinctive feature of shale oil is the high rate of production decline from the well, often by $60 \%-70 \%$ during the first year of operation. This is reflected in higher natural production decline rates compared with conventional oil, where this value varies between $2 \%-14 \%$ depending on the field, with the average of $6.2 \%$ [Fustier et al., 2016].

Another specific feature of shale oil is the insufficient accuracy of the exponential natural production decline law when applied to it, compared with the harmonic or hyperbolic laws [Clark, 2011; Malanichev, $2017 \mathrm{c}]$. Nevertheless, the use of these non-linear laws in expression (1) complicates the integration of the equation and requires further research.

To find an analytical solution for equation (1) in the form of an asymmetric bell-shaped function, two simplifying assumptions were made regarding its coefficients. First, in line with [Saussay, 2018; Kozlov, 2018], we take production decline rate $b$ as a variable, which is consistent with the observational data (Fig. 7). We shall use the following specification: 
$b=k \cdot(\gamma+1) \cdot\left(\frac{Q}{E U R}\right)^{\gamma}$,

where:

$k$ and $\gamma$ are positive empirical coefficients;

$Q$ is the accumulated production volume, $q=d Q / d t$;

EUR (estimated ultimate recovery) is the initial amount of recoverable resources (the sum of already extracted oil and technically recoverable resources).

The Q/EUR ratio serves as the resource depletion rate whose value ranges between $0-1$. As the field's reserves deplete, the natural production decline rate gradually increases (Fig. 7).

Next, we assume the new flow rates $e \cdot N$ are proportional to production volume $q$ :

$e \cdot N=k \cdot q$.

Regression analysis shows a significant correlation by the $t$-statistic criterion between new flow rates and production (Fig. 8). The regression constant is close to zero and statistically indistinguishable from it.

Substituting expressions (2) and (3) in equation (1) and integrating it over time results in an ordinary differential equation describing cumulative production dynamics:

$\frac{d Q}{d t}=k \cdot Q \cdot\left(1-\left(\frac{Q}{E U R}\right)^{\gamma}\right)$.

In form, this is the Bernoulli equation whose analytical solution is an S-shaped Richards function [Richards, 1959]:

$Q(t)=\frac{E U R}{\left(c \cdot e^{-k \cdot \gamma \cdot t}+1\right)^{\frac{1}{\gamma}}}$.

The differentiation of this expression over time produces an asymmetrical bell-shaped function:

$q(t)=Q^{\prime}(t)=\frac{c \cdot k \cdot E U R}{e^{-k \cdot \gamma \cdot t} \cdot\left(c \cdot e^{-k \cdot \gamma \cdot t}+1\right)^{\frac{1}{\gamma}+1}}$,

where the constants $c, k, E U R$ and $\gamma$ can be found by fitting the production curve to the actual data, for example, by the least-squares method. The inflection point of the logistic curve Qinf which corresponds to the peak of production is calculated using the following formula:

$Q_{i n f}=\left(\frac{1}{1+\gamma}\right)^{\frac{1}{\gamma}} \cdot E U R$.

According to assumption (3), the bell-shaped function (6) is used to approximate drilling rig productivity $e(t)$. The curve constants $c, k, \gamma$, and $E$ (cumulative performance, an analogue of $E U R$ ) were found using

\section{Figure 8. Correlation between new flow rates and production in 2007-2017}

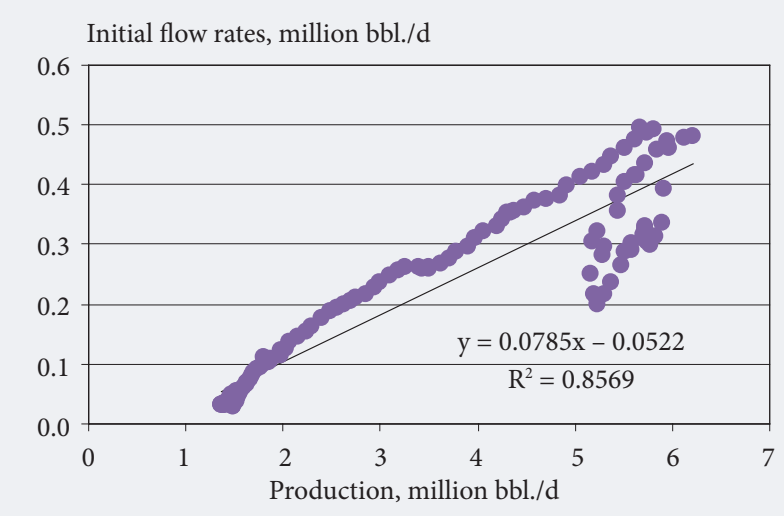

Source: composed by the author based on [EIA, 2018].

\section{Figure 9. Average drilling rigs' productivity}

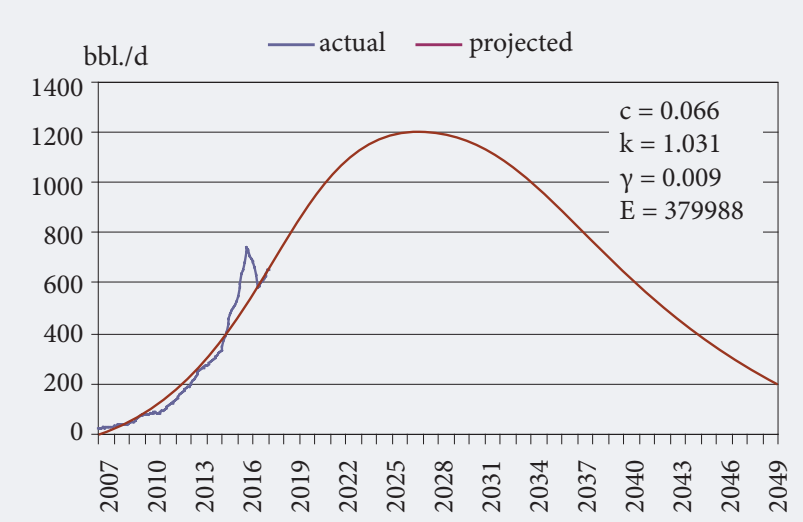

Source: composed by the author based on [EIA, 2018]. 
Economic fluctuations of oil production [Malanichev, 2018]<smiles>[Ge]O[Al]NC=[Ge]</smiles>

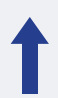

Differential oil production balance equation

$$
\frac{d q}{d t}=e \cdot N-\varphi(q)
$$

Symmetrical bell-shaped curve [Verhulst, 1838; Hubbert, 1956; Malanichev, 2017a]

$$
\begin{aligned}
& \frac{d Q}{d t}=b \cdot Q \cdot\left(1-\frac{Q}{E U R}\right) \\
& e N=q Q 2 b / E U R
\end{aligned}
$$

$\mathrm{t}$ - time

$\tau$ - time lag between the investment

solution and its implementation

Natural production decline rate laws [Malanichev, 2017c]:

$\varphi(q)=b \cdot q$ - exponential

$\varphi(q)=b \cdot q^{2}$ - parabolic

$\varphi(q)=b \cdot q^{a}-$ hyperbolic

Richards asymmetrical bell-shaped curve [Richards, 1959]

$$
\begin{aligned}
& \frac{d Q}{d t}=k \cdot Q \cdot\left(1-\left(\frac{Q}{E U R}\right)^{\gamma}\right) \\
& b=k(\gamma+1) \cdot\left(\frac{Q}{E U R}\right)^{\gamma} \quad e N=k q
\end{aligned}
$$

Source: composed by the author.

the least-squares method over the course of approximating the empirical data on drilling rig productivity averaged for the seven shale formations in the US for the period between 2007-2017 [EIA, 2018]. The optimization procedure was carried out using Excel Solver. The calculations show that productivity will peak by 2026 at $e=1,200$ bbl./d (Fig. 9)

The calculations show that the development of oil production technologies will allow one to double drilling rig productivity compared with the current level. The relevant indicators of the Bakken, Eagle Ford (Fig. 4), and Permian formations confirm that it is physically possible. The latter field also has good growth prospects [Malanichev, 2017c].

If the current level ( $N=800$ units) is taken as the number of active rigs, then according to equation (3) their productivity will peak at the maximum oil production at 11.3 million bbl./d and technically recoverable reserves at 96 billion barrels. Similar values are presented in the literature: for example, the amount of technically recoverable reserves is estimated at 92 billion barrels [EIA, 2015].

The above estimate of the potential shale oil production matches the results obtained using a bell-shaped curve [Malanichev, 2017a], which confirms the validity of the calculations. Under the conservative scenario for the growth of global demand (1 million bbl./d), the potential for increasing production at shale deposits in the United States will be exhausted in five years' time. This may mean that by 2023 they would no longer be able to meet global demand for oil, so other resources, even those with higher production costs, would have to be developed.

\section{Discussion and Conclusion}

At the end of 2017 oil production at shale fields in the United States exceeded 6.3 million bbl./d (6\% of the global oil sales), turning it into a key factor of the emergence of a new market balance. The "shale revolution" became possible due to sufficiently large explored hydrocarbon reserves in tight reservoirs, improved production technologies, and a number of institutional factors. The latter include developed competitive oilfield services markets, the largest drilling rig fleet, an established institution of private land and subsoil ownership, investment and tax incentives for developing low-yield wells, advanced transport infrastructure, environmental requirements favorable for hydraulic fracturing, efficient financial markets including stock exchange insurance tools, and so on.

The main shale oil production technologies (horizontal drilling and hydraulic fracturing) were developed as early as in the first half of the $20^{\text {th }}$ century. Their continuous improvement, the introduction of multicore drilling and multi-stage fracturing, establishing the optimal length of horizontal well sections, and the amount of proppant led to significantly reduced shale oil production costs and made it commercially viable. 
A key factor for reducing shale oil production costs was increased well productivity. For example, at the largest formation in the United States, the Permian field, the average new well production rate steadily grew, from $150 \mathrm{bbl} . / \mathrm{d}$ in 2014 to $450 \mathrm{bbl}$./d in 2017. The entire production cycle is more comprehensively measured by drilling rig productivity, which by the end of 2017 had reached an average of $625 \mathrm{bbl} . / \mathrm{d}$.

Oil rig productivity in the US is affected by five main factors: the development of production technologies, the depletion of deposits, uneven productivity at different fields, the commissioning of reserve wells, and production volume. In the long run, the development of technologies and the amount of technically recoverable reserves turn out to be the most important ones.

In conventional industries, the proliferation of technological innovations that result in productivity growth is typically described by S-shaped curves. However, in the mining industries where technology development has natural limits (i.e., the depletion of natural resources) the situation is different. Technological development initially leads to increased production, but when the reserves in the area being developed are depleted, it decreases. No matter how powerful drilling rigs' drives and injection pumps for hydraulic fracturing are, the laws of natural production decline and depletion of reserves will ultimately lead to reduced oil production and drilling rig productivity.

This paper presents an attempt to develop an analytical tool for the long-term forecasting of shale oil production and the estimation of drilling rig productivity, which would allow one to assess the limits for these indicators' growth. In particular, an asymmetric bell-shaped function was proposed as an analytical solution of the differential production equation (Fig. 10), which describes long-term oil production and drilling rig productivity growth.

An analysis of empirical data based on using the suggested asymmetrical bell-shaped curve shows that the average drilling rig productivity at US shale oil fields may peak by 2026 at 1,200 bbl./d or two times the current level. Production volume will reach 11.3 million bbl./d and technically recoverable reserves will be 96 billion barrels. If that is how things will develop, as early as by 2023, US shale oil producers may be unable to meet the growing global demand for oil, so they would have to start developing other resources with even higher production costs.

The asymmetrical bell-shaped curve, theoretically substantiated and tested on empirical data, can be recommended as a practical and effective tool for conducting Foresight studies of the global oil and gas sector taking into account prospective technological developments.

\section{References}

Afanasiev A.A. (2017) Prognozirovanie dobychi nefti i gazovogo kondensata v vychislimoi modeli denezhnogo obrashcheniya rossiiskoi ekonomiki [Forecasting the production of oil and gas condensate in the computable model of the monetary circulation of the Russian economy]. Ekonomika i matematicheskie metody [Economics and Mathematical Methods], vol. 53, no 2, pp. 50-65 (in Russian).

Arps J.J. (1944) Analysis of decline curves. AIME, no 160, pp. 228-247.

Baffes J., Kose, M.A., Ohnsorge F., Stocker M. (2015) The Great Plunge in Oil Prices: Causes, Consequences, and Policy Responses (PRN 15/01), Washington, D.C.: World Bank Group.

Benes J., Chauvet M., Kamenik O., Kumhof M., Laxton D., Mursula S., Selody J. (2012) The Future of Oil: Geology versus Technology (WP/12/109), Washington, D.C.: International Monetary Fund.

Bierman S., Biryukov A. (2017) Russia's Largest Oilfield May Be About to Gush Cash Once Again. Available at: https:// www.bloomberg.com/news/articles/2017-02-15/siberian-oil-giant-that-bankrolled-soviets-may-gush-cashagain, accessed 05.09.2018.

Brandt A.R. (2010) Review of mathematical models of future oil supply: Historical overview and synthesizing critique. Energy, vol. 35, no 9, pp. 3958-3974.

Clark A.J. (2011) Decline Curve Analysis in Unconventional Resource Plays Using Logistic Growth Models, Austin, TX: The University of Texas in Austin.

Coyne D. (2017) Future US Light Tight Oil (LTO) Update. Available at: http://peakoilbarrel.com/future-us-light-tightoil-lto-update/, accessed 05.09.2018.

Davidsen P.I., Sterman J.D., Richardson G.P. (1990) A petroleum life cycle model for the United States with endogenous technology, exploration, recovery, and demand. System Dynamics Review, vol. 6, no 1, pp. 66-93.

Denning L. (2017) Will Oil Producers Do as They Say or Do as They Sell in 2018? Available at: https://www.bloomberg. com/gadfly/articles/2017-12-13/oil-producer-hedging-data-a-worry-for-opec), accessed 05.09.2018.

EIA (2015) World Shale Resource Assessments, Washington, D.C.: U.S. Energy Information Administration (EIA).

EIA (2016) Expected decrease in Lower 48 oil production is partially offset by rising GOM output. Available at: https:// www.eia.gov/todayinenergy/detail.php?id=25892\#, accessed 05.09.2018.

EIA (2017) U.S. crude oil production forecast expected to reach record high in 2018. Available at: https://www.eia.gov/ todayinenergy/detail.php?id=32192, accessed 05.09.2018.

EIA (2018) Drilling Productivity Report (March), Washington, D.C.: U.S. Energy Information Administration (EIA).

Ermolina A. (2017) Modelirovanie predlozheniya traditsionnoi nefti na osnove fizicheskikh i ekonomicheskikh faktorov (magisterskaya dissertatsiya) [Conventional oil supply modelling based on physical and economic factors (Master thesis)], Moscow: NES (in Russian).

Foster R. (1986) Innovation. The Attacker's Advantage, New York: Summit Books.

Fustier K., Gray G., Gundersen C., Hilboldt T. (2016) Global oil supply, London: HSBC Global Research. 
Glushenkova E.I. (2015) Ekologicheskiye posledstviya slantsevoy revolyutsii [Ecological consequences of the shale revolution]. Zapad - Vostok - Rossiya [West - East - Russia], pp. 184-189 (in Russian).

Hotelling H. (1931) The economics of exhaustible resources. Journal of Political Economy, vol. 39, no 2, pp. 137-175.

Hoza M. (2015) The limits of high grading. Available at: https://btuanalytics.com/the-limits-of-high-grading/, accessed 05.09.2018.

Hubbert M.K. (1956) Nuclear Energy and the Fossil Fuels Drilling and Production Practice. Proceedings of the Spring Meeting of the Southern District, Division of Production, American Petroleum Institute, San Antonio, TX: Shell Development Company, pp. 22-27.

Hughes J.D. (2016) Drilling Deeper. A Reality Check on U.S. Government Forecast for a Lasting Tight Oil \& Shale Gas Boom, Santa Rosa, CA: Post Carbon Institute.

IHS (2015) Still an Adolescent, Permian's Wolfcamp Delaware Offers Promising Adulthood as E\&P Operators Expand Development, IHS Says. Available at: https://news.ihsmarkit.com/press-release/energy-power-media/stilladolescent-permians-wolfcamp-delaware-offers-promising-adulth, accessed 05.09.2018.

Ivanov N. (2017a) Slantsy 3.0 [Shale 3.0]. Neftegazovaya vertical, no 17, pp. 12-20 (in Russian).

Ivanov N. (2017b) Slantsevaya neft' na mirovom rynke: novye tendentsii. Doklad dlya Pyatoi mezhdunarodnoi konferentsii "Global'naya energeticheskaya transformatsiya: ekonomika i politika», Moskva, 15 dekabrya [Shale oil in the world market: New trends. Paper for the Fifth International Conference "Global Energy Transformation: Economics and Politics". Moscow, December 15]. Available at: https://www.imemo.ru/files/File/ru/conf/2017/15122017/01_ Ivanov.pdf, accessed 05.09.2018 (in Russian).

Kaufmann R.K., Cleveland C.J. (2001) Oil production in the lower 48 states: Economic, geological, and institutional determinants. Energy, vol. 22, no 1, pp. 27-49.

Kozlov A. (2018) Modelirovanie dobychi slantsevoi nefti na osnove nesimmetrichnoi kolokoloobraznoi krivoi (magisterskaya dissertatsiya) [Modeling the extraction of shale oil on the basis of an asymmetrical bell-shaped curve (Master thesis)], Moscow: NES (in Russian).

Little A.D. (1981) The Strategic Management of Technology, Cambridge, MA: Massachusetts Institute of Technology.

Makarov A., Veselov F., Eliseeva O., Kulagin V., Malakhov V., Mitrova T., Filippov S., Plakitkina L. (2011) Model'noinformatsionnyi kompleks SCANER [Modeling and information complex SCANER], Moscow: ERI RAS (in Russian).

Malanichev A.G. (2017a) Differentsial'noe uravnenie dobychi slantsevoi nefti [Differential equation of shale oil production]. Neft', gaz i biznes [Oil, Gas and Business], no 2, pp. 44-49 (in Russian).

Malanichev A.G. (2017b) Modeli dobychi slantsevoi nefti v SSHA dlya razlichnykh gorizontov prognozirovaniya [The models of shale oil production in the USA for different forecast horizons]. Neft', gaz i biznes [Oil, Gas and Business], no 3, pp. 13-17 (in Russian).

Malanichev A.G. (2017c) Prognoz dobychi nefti na zalezhi Permian na osnove raznostnogo uravneniya [Forecast of oil production at Permian play based on the difference equation]. Problemy ekonomiki i upravleniya neftegazovym kompleksom [Problems of Economics and Management of the Oil and Gas Complex], no 12, pp. 40-45 (in Russian).

Malanichev A.G. (2018) Prognoz dobychi nefti na slantsevykh mestorozhdeniyakh SSHA na osnove analiticheskikh reshenii differentsial'nogo uravneniya s zapazdyvayushchim argumentom [Modelling of economic oscillations of shale oil production]. Zhurnal Novoi ekonomicheskoi assotsiatsii [Journal of New Economic Association], no 2 (38) (in Russian)

Mănescu C.B., Nuño G. (2015) Quantitative effects of the shale oil revolution. Energy Policy, no 86, pp. 855-866.

Mansfield E. (1968) The Economics of Technological Change, New York: W.W. Norton \& Company Inc.

Montgomery J.B., O'Sullivan F.M. (2017) Spatial variability of tight oil well productivity and the impact of technology. Applied Energy, no 195, pp. 344-355.

Okullo S.J., Reynes F., Hofkes M.W. (2014) Modeling Peak Oil and the Geological Constraints on Oil Production (CentER Discussion Paper 2014-036), Tilburg: Tilburg University.

Richards F.J. (1959) A Flexible Growth Function for Empirical Use. Journal of Experimental Botany, no 10 (29), pp. 290-300.

Rogers E. (2002) Diffusion of Innovations (5th ed.), New York: Free Press.

Rystad Energy (2016) North American Shale Report, Oslo: Rystad Energy.

Saussay A. (2018) Can the US shale revolution be duplicated in continental Europe? An economic analysis of European shale gas resources. Energy Economics, no 69, pp. 295-306.

Schilling M.A., Esmundo M.( 2009) Technology S-curves in renewable energy alternatives: Analysis and implications for industry and government. Energy Policy, vol. 37, no 5, pp. 1767-1781.

Semenychev V.K., Kurkin E.I., Semenychev E.V. (2014) Modelling and forecasting the trends of life cycle curves in the production of non-renewable resources. Energy, vol. 75, issue C, pp. 244-251.

Shafrannik Yu.K., Kryukov V.A. (2016) Neftegazovyi sektor Rossii: trudnyi put' k mnogoobraziyu [Russia’s oil and gas sector: A difficult path to diversity], Moscow - Novosibirsk - Tyumen: "Pero" (in Russian).

Sorrel S., Speirs J., Bentley R., Brandt A., Miler R. (2009) Global oil depletion. An assessment of the evidence for a nearterm peak in global oil production, London: UK Energy Research Centre.

Verhulst P.F. (1838) Notice sur la loi que la population suit dans son accroissement. Correspondance mathématique et physique, vol. 10, pp. 113-121.

Zhukov S.V., Zolina S.A. (2017) Finansovyi rynok - draiver rosta neftedobychi v SSHA [Financial Market as a Driver of US Oil Production Growth]. Ekonomika i organizatsiya promyshlennogo proizvodstva [Economics and industrial production organization], no 10, pp. 85-96 (in Russian).

Zolina S.A. (2014) Prognozirovanie dobychi trudnoizvlekaemoi nefti v SSHA [Forecasting the extraction of hard-torecover oil in the US], Moscow: IMEMO RAS (in Russian). 